\title{
Circulação de ideias: a influência de Melville Herskovits na trajetória intelectual de Arthur Ramos (1935-1949)
}

\author{
Heloísa Maria Teixeira ${ }^{1}$
}

\begin{abstract}
Resumo: Analisamos a correspondência entre Arthur Ramos e o antropólogo norteamericano Melville Herskovits durante o período de 1935 a 1949, época de sistematização dos estudos afro-americanos. As epístolas entre os dois intelectuais nos revelam um intenso intercâmbio de ideias envolvendo trocas de materiais bibliográficos, pesquisas e divulgação das produções dos estudiosos dos africanismos no Novo Mundo. As fontes mostram ainda as discussões comumente presentes nas correspondências em torno do racismo nas sociedades americanas. Nosso ponto central, portanto, é demonstrar como o envolvimento profissional e pessoal com Herskovits foi o mais importante ponto de inflexão do pensamento ramista em duas situações: quando sua obra secundariza a abordagem médico-psicanalítica para dar protagonismo à Antropologia Cultural, por volta de 1935; e, ao perceber a insuficiência das discussões acadêmicas no contexto da Segunda Guerra Mundial, volta-se à Antropologia Aplicada - que não estava no escopo de seu interlocutor de Northwestern, mas era efervescente em outras instituições americanas pelas quais passou.
\end{abstract}

Palavras-chave: Circulação de ideias; Arthur Ramos; Melville Herskovits; Estudos AfroAmericanos; Estudos Afro-Brasileiros; Luta antirracista.

\section{Circulation of ideas: Melville Herskovits influence on the intellectual trajectory of Arthur Ramos (1935-1949)}

\begin{abstract}
The exchange of letters between Arthur Ramos and North-American Anthropologist Melville Herskovits, from 1935 to 1949, hás been analyzed, embracing a period in which the afro-american studies started being systematized. The communication between the two intellectuals has revealed an intensive interchange of ideas and exchange of bibliographic material, researches and dissemination of results from africanist scholars in the New World. Besides, the sources show the discussions about racism in American societies, often present in the letters. Our central point, therefore, intends to demonstrate how the professional and personal involvement with Herskovits was the most important turning point of Ramos thought in two situations: when his work converted the medical-
\end{abstract}

\footnotetext{
${ }^{1}$ Doutora em História - Universidade de São Paulo. Pós-doutoranda em História - Universidade Federal de Ouro Preto. Email: heloisate@ hotmail.com
}

\section{GANPHLAC}


psychoanalytic approach just a supporting to a culturalistic perspective around 1935; and when, realizing the failure of academic discussions in the context of World War II, he turns to Applied Anthropology - which was not within the scope of his Northwestern interlocutor, but was too debated in other American institutions which he passed.

Keywords: Circulation of ideas; Arthur Ramos; Melville Herskovits; Afro-American Studies; Afro-Brazilian Studies; anti-racist fight.

Artigo recebido em: 31/05/2019

Artigo aprovado para publicação em: 28/10/2019

\section{Introdução}

A intensa produção acadêmica nas Américas ao longo das décadas de 1930 e 1940 acerca da identidade africana no Novo Mundo é desconhecida do grande público. Entretanto, marcou uma reviravolta no olhar sobre a contribuição da cultura africana para a construção social nas Américas e o combate ao racmo.

Os chamados Estudos Afro-Americanos surgiram nos EUA - a partir de pioneiros como W.E.B. Du Bois e Carter G. Woodson - no início do século XX e cresceram durante os anos 30, como consequência do desenvolvimento da antropologia culturalista, cujo maior expoente foi Franz Boas. A partir de então, o culturalismo substituiria a noção biológica de raça - conceito-chave para a teoria da Antropologia Física - na compreensão das diferenças humanas pelo conceito de cultura.

Naquele período, nasciam análises que defendiam a "tese da sobrevivência"2 das formas culturais africanas no Novo Mundo, isto é, a capacidade que os negros tiveram de sobreviver à opressão branca, mantendo relativamente intactas suas expressões culturais trazidas da África. O nome mais destacado dessa corrente é o do antropólogo norte-americano de origem judia Melville Herskovits. O principal argumento de Herskovits era a ideia de que os escravos vinham de áreas relativamente restritas do continente africano - uma faixa litorânea que se estendia do Senegal até Angola, com influência mais decisiva da Costa do Ouro a Costa dos Escravos -, existindo entre eles

\footnotetext{
${ }^{2}$ A classificação é de Orlando Patterson, que propôs as expressões "tese da catástrofe" e "tese da sobrevivência" como formas de identificar, em posições marcadamente distintas, duas correntes de estudos sobre a questão do negro nas Américas.
}

\section{GANPHLAC}

Revista Eletrônica da ANPHLAC, ISSN 1679-1061, № 27, p. 185-221, Ago./, Dez., 2019.

http://revista.anphlac.org.br 
princípios culturais compartilhados por toda a área do tráfico, o que ele chamou de "gramática da cultura" africana. Segundo o autor, a presença das divindades religiosas originárias da costa africana nos cultos religiosos praticado nas Américas comprova a ligação cultural entre África e Novo Mundo, tendo permitido que costumes e valores de origem africana sobrevivessem e fossem compreendidos e adotados mesmo pelos africanos cuja ascendência étnica era distinta. Para Herskovits

\section{um grau suficiente de similaridade nas culturas de toda a área, de modo que um escravo de qualquer parte dela não teria dificuldade em si adaptar a quaisquer formas específicas de comportamento africano que ele viesse a encontrar no Novo Mundo (HERSKOVITS, 1990, 78).}

Em oposição, a "tese da catástrofe" acreditava que a escravidão teria representado a quase total falência cultural dos africanos e seus descendentes nas Américas (MARQUESE, 2004, p. 303-304). Entre seus adeptos, estavam o sociólogo negro norte-americano Franklin Frazier e o historiador Stanley Elkins, também norteamericano. Frazier enfatizou a universalidade da condição humana e o caráter intrinsecamente mutável de todas as formas culturais e sociais. Autor do famoso livro The black family in the United States, publicado em 1939, afirmava que a escravidão e a pobreza foram os principais fatores que influenciaram a estrutura familiar da população negra. Para ele, a memória cultural dos africanos teria se fragmentado e se perdido devido às circunstâncias da escravidão. Segundo o autor, "provavelmente nunca antes na história um povo foi tão completamente privado de sua herança social quanto os negros trazidos à América" (FRAZIER, 1939). Para Frazier, despojados de sua herança cultural, os negros teriam permanecido em estado de anomia social, desestruturando as instituições familiares dos negros.

Sobre esse debate, Livio Sansone nos lembra de que entre 1941 e 1943, a cidade baiana de Salvador se tornou palco de estudos para seus maiores representantes: Franklin Frazier e Melville Herskovits ${ }^{3}$. Alimentando o debate entre os dois diferentes

\footnotetext{
${ }^{3}$ Não somente Herskovits e Frazier dedicaram estudos sobre o negro baiano. Destacamos também Donald Pierson, Ruth Landes e Lorenzo Dow Turner. Este último chegou a Salvador junto de Frazier (SANSONE, 2012).
}

\section{CANPHLAC}

Revista Eletrônica da ANPHLAC, ISSN 1679-1061, № 27, p. 185-221, Ago./, Dez., 2019.

http://revista.anphlac.org.br 
entendimentos sobre a integração do negro no Novo Mundo, o sociólogo Frazier e o antropólogo Herskovits refletiram sobre as origens e as formas culturais negras, especialmente a "família negra" no Novo Mundo, por meio de pesquisa de campo realizada com o povo de santo do terreiro do Gantois, de nação queto-iorubá. Sansone sintetiza a discussão travada entre os estudiosos estadunidenses com duas indagações:

A cultura e a estrutura familiar negras seriam o resultado da escravidão e mais tarde a adaptação à pobreza? Ou seriam o resultado de africanismos, de formas tradicionais africanas de vida e de cultura adaptadas ao novo mundo? (SANSONE, 2012, p.10).

Frazier e Herskovits entrevistaram o mesmo grupo de pessoas e perceberam que as famílias matrifocais predominavam na comunidade baiana, entretanto, as explicações para tal característica divergiram entre si. Para Frazier, a matrifocalidade era uma adaptação criativa à vida sob condições sociais incertas, uma estratégia de sobrevivência dos pobres em diversas partes do globo, a despeito de qualquer padrão cultural. Para o sociólogo, as ações cotidianas, as estratégias de sobrevivência e os arranjos familiares eram informados muito mais pelas circunstâncias do presente que por qualquer passado africano. Já para Melville Herskovits, os africanismos explicavam os arranjos familiares matrifocais dos negros baianos. Para ele, a matrifocalidade era essencialmente um padrão familiar característico da África Ocidental que se tinha mantido vivo ao longo dos tempos.

Os estudos norte-americanos influenciaram o pensamento de vários intelectuais brasileiros. Entre eles, Arthur Ramos, que durante as décadas de 1930 e 1940, estabeleceu intenso diálogo com acadêmicos de vários pontos do continente americano que discutiam a influência africana na identidade cultural do Novo Mundo. Como resultado desse intercâmbio intelectual, percebe-se um crescimento das pesquisas no Brasil acerca da nossa multiplicidade cultural, especialmente aquela ligada ao continente africano. Essa produção ficou conhecida como Estudos Afro-Brasileiros ${ }^{4}$.

\footnotetext{
${ }^{4}$ No Brasil, esses estudos questionam as teorias raciais que tomam força nos anos de 1870, oriundas da ciência raciológica europeia, aqui reapropriadas de acordo com a singularidade do Brasil mestiço. Singularidade esta que era vista de forma bastante negativa, pois a presença de etnias inferiores misturadas, principalmente o
}

\section{GANPHLAC}

Revista Eletrônica da ANPHLAC, ISSN 1679-1061, № 27, p. 185-221, Ago./, Dez., 2019.

http://revista.anphlac.org.br 
Era a primeira vez que estudos desenvolviam análises positivas sobre a herança cultural de origem africana na sociedade brasileira. Como afirma Livio Sansone, "em termos culturais, a África estava começando a ser encarada como um bônus - um recurso na coluna dos ativos -, depois de ter passado séculos como um ônus - na coluna dos passivos" (SANSONE, 2012, p. 11).

O período em foco se destaca pela ascensão dos regimes totalitários, o sentimento segregacionista e a tensão do expansionismo alemão. Nesse contexto, as universidades norte-americanas discutiam temas tais como democracia e raça e dialogavam com demandas de movimentos sociais, refutando teses do cientificismo racista daqueles tempos. Aqui, um grupo de pensadores emitiu em 1935 o Manifesto dos Intelectuais Brasileiros contra o Preconceito Racial, denunciando a ameaça que representava a ciência racial nazista para o Brasil por "comprometer a coesão social" em um país de grande "diversidade" étnica ao disseminar o preconceito racial. Arthur Ramos e Gilberto Freyre, entre outros, assinaram a declaração ${ }^{5}$.

O período analisado também deve ser caracterizado pela consolidação das Ciências Sociais e Humanas no Brasil. O crescimento dos Estudos Afro-Brasileiros como campo de estudo contribuiu para a afirmação, ampliação, sistematização e legitimação das pesquisas científicas. Para Arthur Ramos, nesse período representou uma preocupação a instituição das bases para uma antropologia acadêmica nacional. Mais uma vez, o intercâmbio intelectual com acadêmicos internacionais tem um importante papel. Segundo Sansone,

não há história da antropologia e de disciplinas correlatas que seja exterior à geopolítica do conhecimento. Isso implica que há um norte e um sul globais nas trocas intelectuais, com relações complexas entre pesquisadores do norte e do sul - em que os últimos são, na maioria das vezes, embora não

enorme contingente negro, estava "degradando" a civilização brasileira e "condenando" seu futuro (SCHWARCZ, 1993). Nos anos de 1930, a mestiçagem passa a ser exaltada como o elemento unificador, o diferencial positivo da sociedade brasileira.

${ }^{5}$ Manifesto dos Intelectuais Brasileiros contra o Preconceito Racial. In Guerra e relações de raça. Rio de Janeiro: Departamento Editorial da União Nacional de Estudantes, 1943, p. 173. O Manifesto foi um dos resultados do I Congresso Afro-Brasileiro, realizado em Recife. Os outros signatários foram Inácio do Amaral, Roquette-Pinto, Maurício de Medeiros, Hermes Lima, Joaquim Pimenta, Queiroz Lima, Castro Rebello, Leônidas de Rezende, Victor Vianna e Azevedo Amaral.

\section{GANPHLAC}

Revista Eletrônica da ANPHLAC, ISSN 1679-1061, № 27, p. 185-221, Ago./, Dez., 2019.

http://revista.anphlac.org.br 
exclusivamente, fornecedores de evidência etnográfica, contatos locais e intuições sagazes, mas raramente a fonte de generalizações teóricas universalmente válidas -, e que a posição do pesquisador nessa troca é indicativa de sua abordagem e de sua agenda (SANSONE, 2012).

Contemporâneo a três importantes nomes das ciências sociais brasileiras Gilberto Freyre, Sérgio Buarque de Holanda e Caio Prado Junior -, Arthur Ramos acabou por ser relegado ao segundo escalão, enquanto "autor menor" (CAMPOS, 2004, p. 41-42). Certamente vários fatores contribuíram para esse ostracismo, tais como o embate entre adversários em relações político-acadêmicas, as orientações teóricas, sua morte prematura, aos 46 anos, no auge de sua carreira etc.

De 1926 a 1949, escreveu aproximadamente 500 trabalhos, muitos dos quais ainda inéditos e que compõem parte do Arquivo Arthur Ramos, tutelado pela Biblioteca Nacional.

O Arquivo Arthur Ramos contém cerca de 5 mil documentos distribuídos em correspondência do titular e de terceiros (que perfaz a maior parte do acervo, quase três mil documentos), recortes de jornais, folhetos, fotografias, manuscritos, pesquisas e estudos sobre educação, medicina legal, psiquiatria, psicologia, sociologia, antropologia, folclore e etnografia.

Intelectual de intensas relações com seus pares no Brasil e no exterior, Arthur Ramos foi figura central na articulação e circulação de ideias sobre as raízes culturais africanas no Novo Mundo. As correspondências do alagoano com intelectuais de várias partes do mundo, sobretudo norte-americanos, criaram um percurso para a compreensão dos estudos sobre os negros nas Américas, além de serem reveladoras de um ativo movimento antirracista em um período no qual esse tipo de militância não tinha fácil penetração social.

\section{A trajetória intelectual de Arthur Ramos}

Arthur Ramos nasceu em Pilar, Alagoas, no ano de 1903. Em 1926, formou-se médico pela Faculdade de Medicina da Bahia, sendo que no mesmo ano defendeu a tese

\section{GANPHLAC}

Revista Eletrônica da ANPHLAC, ISSN 1679-1061, № 27, p. 185-221, Ago./, Dez., 2019.

http://revista.anphlac.org.br 
Primitivo e Loucura. Nesse período, conheceu os estudos de Raimundo Nina Rodrigues sobre a cultura religiosa de origem africana na Bahia. ${ }^{6}$ A partir desse contato, iniciou-se seu interesse pela cultura afro-brasileira. Ao longo das duas décadas seguintes, firmouse como um dos principais estudiosos sobre o negro na identidade brasileira.

Nomeado por Anísio Teixeira chefe da seção técnica de Ortofrenia e Higiene Mental do Departamento de Educação da Secretaria Geral de Educação e Cultura, no Distrito Federal, mudou-se em 1934 para o Rio de Janeiro. Na mesma época, tornou-se professor de Psicologia Social na Universidade do Distrito Federal, tendo posteriormente sido professor de Antropologia e Etnologia na Faculdade Nacional de Filosofia (FNFi), criada no ano de 1939.

Juntamente a outros intelectuais nordestinos, como Afrânio Peixoto, Anísio Teixeira e Édison Carneiro, formou um centro para pesquisa das relações raciais no Brasil, consagrado como Escola Nina Rodrigues. Radicados no Rio de Janeiro, a atuação conjunta desses intelectuais permitiu a edição ou reedição dos trabalhos de Nina Rodrigues e dos membros do próprio grupo, por meio da Coleção Biblioteca de Divulgação Científica, dirigida por Arthur Ramos e publicada pela Editora Civilização Brasileira. Segundo Mariza Corrêa, a partir da Escola Nina Rodrigues, solidificou-se a perspectiva africanista dos estudos etnográficos realizados na Bahia. Intitulados discípulos de Nina, os idealizadores da Escola revisitaram os materiais de campo por ele coletados em Salvador no final do século XIX, interpretados à luz de teorias do racismo científico, e os ressignificaram sob um viés culturalista ${ }^{7}$. Ramos e seus pares buscaram legitimar seus próprios trabalhos mediante a reivindicação de uma filiação aos estudos

\footnotetext{
${ }^{6}$ Nina Rodrigues (1862-1906), médico e pesquisador baiano, analisou fenômenos médicos na população afro-baiana guiando-se pelo racismo biológico. Como médico, a preocupação de Nina era entender os motivos patológicos da criminalidade e de outros comportamentos considerados desviantes e anormais, supostamente observáveis nos candomblés.

${ }^{7}$ Segundo o antropólogo Luiz Fernando Dias Duarte, é reconhecível a importância de Nina Rodrigues para a formação de Arthur Ramos, entretanto, este "transmutou essa herança - afirmada por ele -a patamares muito diferentes, muito mais amplos e complexos de interpretação dos fenômenos culturais brasileiros" (DUARTE, 1999, p.20).
}

\section{CANPHLAC}

Revista Eletrônica da ANPHLAC, ISSN 1679-1061, № 27, p. 185-221, Ago./, Dez., 2019.

http://revista.anphlac.org.br 
de Nina, em um momento de "renhida disputa político-intelectual" sobre o pioneirismo dos estudos sobre o negro (SILVA, 2015, p.197) ${ }^{8}$.

Importantes livros sobre temas afro-brasileiros foram publicados na Coleção Biblioteca de Divulgação Científica. Entre 1934 e 1940, a coleção dirigida por Arthur Ramos editara: O negro brasileiro, Arthur Ramos (1934); O animismo fetichista dos negros baianos, Nina Rodrigues (1934); Questões de Antropologia brasileira, Bastos de Ávila (1935); O folclore negro no Brasil, Arthur Ramos (1935); Alimentação e raça, de Josué de Castro (1935); Hereditariedade e eugenia, Octaviano Domingues (1936); Religiões negras, Édison Carneiro (1936); Valor social da alimentação, Ruy Coutinho (1937); Novos Estudos Afro-Brasileiros, Gilberto Freyre e outros (1937, reunindo os trabalhos apresentados ao I Congresso Afro-Brasileiro, realizado em Recife); $O$ português no Brasil, Renato Mendonça (1937); A escrita pré-histórica do Brasil, Alfredo Brandão (1937); As culturas negras do Novo Mundo, Arthur Ramos (1937); Xangôs do Nordeste, Gonçalves Fernandes (1937); Negros Bantus, Édison Carneiro (1937); Costumes africanos no Brasil, Manuel Querino (1938); Preparação ao método científico, de Djacir Menezes(1938), As coletividades anormais, de Nina Rodrigues (1939) e O negro no Brasil (1940, reunindo os trabalhos apresentados ao II Congresso Afro-Brasileiros, realizado na Bahia em janeiro de 1937).

Foi a partir da circulação da obra $O$ negro brasileiro: etnografia religiosa $e$ psicanálise (1934) que Arthur Ramos iniciou uma série de debates com cientistas sociais norte-americanos vinculados à Antropologia Culturalista, que a partir de então exerceu forte influência sobre suas obras ${ }^{9}$. As mudanças metodológicas já puderam ser sentidas

\footnotetext{
${ }^{8}$ Outro objetivo do grupo radicado no Rio de Janeiro era enfrentar a hegemonia da perspectiva freyreana sobre as relações raciais, calcada na mestiçagem.

${ }^{9}$ Até o início do século XX, o paradigma evolucionista era dominante na etnologia cultural. De acordo com esse paradigma, todas as sociedades se desenvolveriam segundo princípios idênticos, adotando os mesmos costumes de acordo com leis gerais de desenvolvimento, as quais estabeleciam um processo unilinear e teleológico de evolução cultural a ser percorrido por todas as sociedades, passando por diversos graus e estágios de cultura em ritmos distintos. Dessa forma, haveria um único caminho possível - representado pela civilização ocidental europeia - de desenvolvimento cultural. Boas critica esse pressuposto afirmando que não haveria um único percurso possível de desenvolvimento cultural. Para ele, a história do desenvolvimento cultural ocidental não poderia ser projetada para outras sociedades e nem
}

\section{CANPHLAC}

Revista Eletrônica da ANPHLAC, ISSN 1679-1061, № 27, p. 185-221, Ago./, Dez., 2019. http://revista.anphlac.org.br 
nos trabalhos que se sucederam: O folclore negro no Brasil (1935) e As culturas negras no Novo Mundo (1937). A antropóloga Luitgarde Barros afirma que a partir da publicação de $O$ negro brasileiro, Arthur Ramos atuará "como médico psiquiatra e antropólogo, até a morte” (BARROS, 2000, p.29).

Entre 27 de agosto de 1940 e maio de 1941, Arthur Ramos - junto à sua esposa, Dona Luiza - realizou uma viagem de estudos aos Estados Unidos. Naquela situação, Ramos pretendia buscar "a autoridade que julgava galgar em torno dos então chamados Estudos Afro-Brasileiros e a singular posição política do Brasil nesse contexto intelectual" (CUNHA, 1999, p.72). Para Olívia Maria da Cunha, "a viagem fora concebida como um rito de iniciação. Além de dotar de prestígio a sua carreira, o transformara de fato num antropólogo" (CUNHA, 1999, p.85). Nos anos de 1940, Ramos efetivou

deslocamentos teóricos relevantes em suas análises sobre o que chamava "culturas afro-brasileiras". Do seu Notas de etnologia (1932) à Introdução à Antropologia brasileira (1943) e Poblaciones del Brasil (1945), reflexões inspiradas em Freud e Lévy-Bruhl deram lugar a proposições em torno das relações entre "raça" e "cultura", baseadas em Franz Boas e Melville Herskovits (CUNHA, 1999, p.87-88).

Retornou ao Brasil para se dedicar às aulas na Universidade do Brasil - onde lecionava Antropologia e Etnologia na Faculdade Nacional de Filosofia (FNFi) desde 1939 - e à fundação da Sociedade Brasileira de Antropologia e Etnologia (SBAE). Nesse período, Ramos encabeça um conjunto de ações que visam combater o racismo.

A partir daí, Ramos se direcionou a uma antropologia aplicada na superação do racismo, afastando-se da abordagem africanista. Arthur Ramos passou a difundir a "democracia racial" do Brasil como modelo para o mundo, algo capaz de contribuir para a superação das mazelas ocasionadas pelo racismo. Para tanto, caberia aos antropólogos o papel de ressaltar "a universalidade das misturas [apontando para] a conclusão lógica

deduzida a partir delas. Com isso, Boas buscava um fundamento histórico e particularista para estudar a cultura, indicando a história de um fenômeno como dado essencial para sua compreensão, já que seria marcado pela sua trajetória particular, pelas determinações que motivaram seu desenvolvimento em um contexto específico. Assim sendo, os enunciados sobre uma cultura só poderiam ser verdadeiros em relação àquela cultura particular, não podendo ser aplicados a outras que fossem portadoras de desenvolvimentos históricos distintos (MARCUSSI, 2016; STOCKING Jr.1999).

\section{GANPHLAC}

Revista Eletrônica da ANPHLAC, ISSN 1679-1061, № 27, p. 185-221, Ago./, Dez., 2019.

http://revista.anphlac.org.br 
[de] que a civilização nada tem a ver com a cor da epiderme, a forma dos cabelos ou a cor dos olhos" (RAMOS, Arthur, The Negro in Brazil. Washington: The Associated Publishers, 1939, apud MAIO, 1999, p.34).

Em seus programas do curso de Antropologia Brasileira, nos anos de 1940, Arthur Ramos ressaltava os diversos grupos raciais e étnicos existentes no Brasil. Para Ramos, o entendimento dos processos de mudança social, inseridos nos diversos contextos históricos, devia ser objeto de estudo pelas Ciências Sociais, a partir do que entenderíamos as desigualdades étnico-raciais vigentes em nossa sociedade (MAIO, 1999, p.32). Em sua perspectiva,

só depois de realizadas séries inteiras de pesquisas desta ordem, poderemos nos aventurar a propor "interpretações" do Brasil, ensaios de conjunto ou planos normativos de ação, até agora reservados aos estudos impressionistas que podem ser muito interessantes, mas conduzem a generalizações apressadas e perigosas. (...) Do ponto de vista antropológico, não há uma "cultura" brasileira, mas "culturas" que só agora começam a ser estudadas e compreendidas. Ainda é cedo, portanto, para indagarmos do "caráter nacional" do seu ethos, em visões generalizadoras que lancem mão do critério histórico ou social (RAMOS, 2015. p. 210).

A institucionalização das ciências sociais em curso no Brasil possibilitaria a superação da fase "livresca, literatoide dos estudos antropológicos sobre o índio e o negro" (RAMOS, 2015). Segundo o alagoano, os novos estudos deveriam considerar o passado escravocrata e suas implicações para o entendimento da situação racial brasileira, especialmente "a influência psicossociológica dos grupos dominantes, não negros, as relações de 'raça', os estereótipos de opiniões e atitudes, os fatores sociológicos da casta e da classe" (RAMOS, 2015, pp. 202-206).

Os estudos acerca do negro no Brasil e seu engajamento na luta contra o racismo fizeram de Ramos uma autoridade reconhecida em nível internacional. Em reconhecimento à sua importância, em meados de 1949 recebeu o convite para chefiar o recém-criado Departamento de Ciências Sociais da Organização das Nações Unidas para a Educação, Ciência e Cultura (Unesco). Faleceu a 10 de agosto de 1949, três meses após se mudar para Paris para assumir o cargo.

\section{CANPHLAC}

Revista Eletrônica da ANPHLAC, ISSN 1679-1061, № 27, p. 185-221, Ago./, Dez., 2019.

http://revista.anphlac.org.br 


\title{
Ideias circulantes: Arthur Ramos e Melville Herskovits
}

Conforme enfatiza Angela de Castro Gomes, o convívio entre intelectuais é fundamental para o desenvolvimento de ideias.

\begin{abstract}
Para escrever, pintar, compor etc., o intelectual precisa estar envolvido em um circuito de sociabilidade que, ao mesmo tempo, o situe no mundo cultural e lhe permita interpretar o mundo político e social de seu tempo. Por isso afirma-se que não é tanto a condição de intelectual que desencadeia uma estratégia de sociabilidade e, sim, ao contrário, a participação numa rede de contatos é que demarca a específica inserção de um intelectual no mundo cultural. Intelectuais são, portanto, homens cuja produção é sempre influenciada pela participação em associações, mais ou menos formais, e em uma série de outros grupos, que se salientam por práticas culturais de oralidade e/ou escrita (GOMES, 2004, p.51) ${ }^{10}$.
\end{abstract}

A correspondência pessoal entre intelectuais é um lugar de sociabilidade fundamental e revelador da dinâmica dos envolvidos e do campo cultural e político de um dado período. Lugar de sociabilidade, como afirma Gomes, "entendido como espaço de constituição de uma rede organizacional que pode ser mais ou menos formal/institucional e como um microcosmo de relações afetivas (de aproximação e/ou de rejeição)" (GOMES, 2004, p.52-53). Entre as linhas escritas, o autor das missivas expõe ideias, projetos, opiniões, interesses e sentimentos.

\section{De acordo com Olívia Maria Gomes da Cunha}

não só pessoas cruzam fronteiras, mas suas ideias, emolduradas em suportes variados - como o livro, o artigo publicado, o nome citado, a resenha referida -, são poderosos instrumentos de projeção e transposição dos autores para fora dos limites nos quais sua criação foi concebida (CUNHA, 1999, p.75).

Em 1934, a publicação de $O$ negro brasileiro: etnografia religiosa e psicanálise marcou a entrada de Arthur Ramos no circuito intelectual que discutia os africanismos no Novo Mundo. Entre seus interlocutores, destacamos Donald Pierson (sociólogo estadunidense); Richard Pattee (historiador canadense); Lynn Smith (sociólogo estadunidense); Rüdiger Bilden (historiador alemão, radicado nos Estados Unidos);

\footnotetext{
${ }^{10}$ Angela de Castro Gomes analisou a troca de correspondências entre o historiador Manoel de Oliveira Lima e o sociólogo Gilberto Freyre, ambos pernambucanos, durante as décadas de 1910 e 1920 . Trata-se de um conjunto de 180 cartas, sendo 100 de Freyre e 80 de Lima. A troca de correspondência se estende de abril de 1917 a junho de 1927 (GOMES, 2004).
}

\section{GANPHLAC}

Revista Eletrônica da ANPHLAC, ISSN 1679-1061, № 27, p. 185-221, Ago./, Dez., 2019.

http://revista.anphlac.org.br 
Lewis Hanke (historiador estadunidense), Melville J. Herskovits (antropólogo estadunidense) e outros.

Neste artigo, analisaremos o intercâmbio de ideias firmado entre Arthur Ramos e Melville Herskovits por meio da troca epistolar estabelecida no período de 1935 e 1949. Herskovits, antropólogo internacionalmente conhecido por suas pesquisas sobre o continente africano e sobre os africanismos no Novo Mundo, destacou-se pelos estudos de campo e pelas análises que evidenciavam a proximidade entre a cultura africana e tradições afro-americanas. Em 1934, passou pouco mais de três meses na aldeia haitiana de Mirebalais e os resultados da pesquisa foram publicados no ano de 1937 sob o título de Life in a Haitian valley, uma representação da prática do vodu haitiano. Além deste, destacam-se entre suas obras: The cattle complex in east Africa (Ph.D Dissertation, 1923); The negro's americanism (ensaio publicado no livro The new negro, publicado por Alain Locke, 1925); The american negro(1928); Rebel destiny, among the bush negroes of Dutch Guiana (1934); Acculturation: The Study of Culture Contact (1938); Economic life of primitive people (1940); The myth of the negro past (1941); Trinidad village (1947); Continuity and change in african culture (1959); The human factor in changing Africa (1962); Economic transition in Africa (1964).

Em 1935, ano de início do intercâmbio com Arthur Ramos, o africanista americano tinha 45 anos e estava solidamente estabelecido na Northwestern University (GUIMARÃES, 2004, p.171). Foi Herskovits quem iniciou o contato com Ramos por meio de um bilhete solicitando um exemplar de $O$ negro brasileiro.

Não encontramos o retorno de Arthur Ramos entre a correspondência pesquisada, porém, em 31 de dezembro de 1935, Melville Herskovits escreve a Ramos acusando o recebimento da missiva e agradecendo os livros enviados ( $O$ negro brasileiro; Os africanos no Brasil, de Nina Rodrigues; e A escravidão no Brasil, de Evaristo de Moraes $)^{11}$. Nessa mesma carta, Herskovits lhe enviou algumas separatas de

\footnotetext{
${ }^{11} \mathrm{O}$ sociólogo Antônio Sérgio Alfredo Guimarães afirma que a correspondência entre Ramos e Herskovits se inicia por recomendação de Gilberto Freyre (GUIMARÃES, 2004). Em carta enviada ao antropólogo, em 18 de julho de 1935, Freyre diz: "Escrevi a meus editores em São Paulo para que lhes mandem os livros.
}

\section{GANPHLAC}

Revista Eletrônica da ANPHLAC, ISSN 1679-1061, № 27, p. 185-221, Ago./, Dez., 2019.

http://revista.anphlac.org.br 
artigos de sua autoria e disse que seu editor, Alfred A. Knopf, enviar-lhe-ia alguns de seus livros. A animação de Herskovits por $O$ negro brasileiro é visível:

Os livros chegaram a mim apenas ontem, obviamente não me foi possível mais que folheá-los, mas, ainda assim, há um número de questões que gostaria de fazer-lhe. A primeira delas diz respeito às peças mostradas nas Figuras 4, 5, 34 e 35. Elas se assemelham tanto às peças que eu mesmo coletei no Daomé e Nigéria que eu gostaria de ter certeza de que é correta a minha impressão sobre sua proveniência brasileira. Se este for o caso, então, seus negros brasileiros mantiveram não apenas a técnica de escultura em madeira, mas os mesmos detalhes do estilo da África Ocidental em um grau não encontrável em nenhum outro lugar (AAR/BN, I-35, 31, 1.429, Illinois, $31 / 12 / 1935)^{12}$.

Herskovits também observou que

muitas das canções têm assuntos que as conectam muito com os dados haitianos que eu colhi numa viagem de campo no penúltimo verão. Deste modo, a Zambiapongo sobre a qual você falou na página 81 é o mesmo que Zambi ampaka dos haitianos, que da mesma forma, tem Lemba como uma de suas divindades Petro (AAR/BN, I-35, 31, 1.429, Illinois, 31/12/1935).

Destacou, ainda, o sincretismo descrito na obra.

Um capítulo que eu estou ansioso para ler com particular interesse é o da combinação da Feitiçaria e o Catolicismo, e eu espero fazer bom uso de sua lista de analogias entre santos católicos e divindades da feitiçaria. Particularmente interessante nesse contexto são suas Figuras 19 e 20 que eu poderia quase duplicar com fotografias do Haiti, uma das quais, mostrando um altar vodu com símbolos católicos, estou anexando, já que pode lhe interessar. É esta combinação das religiões africanas e europeias que, para mim foi, de longe, o aspecto mais interessante da religião haitiana (AAR/BN, I-35, 31, 1.429, Illinois, 31/12/1935).

As passagens descritas acima demonstram o entusiasmo de Herskovits ao descobrir que a Bahia mantinha tradições religiosas semelhantes às do Daomé - de onde

Eles [Referindo-se à coleção da Biblioteca de Divulgação Científica] publicaram sobre a antropologia e sociologia do negro e do Brasil em geral vários livros, incluindo Nina Rodrigues Os africanos no Brasil, Evaristo de Moraes A Escravidão no Brasil, Arthur Ramos O Negro Brasileiro". Carta de Gilberto Freyre dirigida a Herskovits, Rio de Janeiro, 18 de julho de 1935. Tradução Antônio Sérgio Alfredo Guimarães (GUIMARÃES, 2004, p.188).

${ }^{12}$ As figuras apresentadas por Arthur Ramos em seus livros também foram admiradas por Roger Bastide. Em carta escrita em 26 de maio de 1939, Bastide revela que Theodore Monod, diretor do Instituto Francês da África Negra em Dakar, ao tomar conhecimento da obra As culturas negras no Novo Mundo, de autoria de Ramos, perguntou-lhe se as esculturas de Exu, Erê e Xangô da figura 9 do seu livro seriam objetos de origem africana antiga ou recente ou objetos brasileiros. Continuando, Bastide comenta: "eu acho que eles são definitivamente objetos brasileiros; mas eu não quero responder a ele sem me informar com você" (AAR/BN, I-35, 22, 622, São Paulo, 26/5/1939).

\section{GANPHLAC}

Revista Eletrônica da ANPHLAC, ISSN 1679-1061, № 27, p. 185-221, Ago./, Dez., 2019.

http://revista.anphlac.org.br 
vieram parte dos africanos escravizados para a América - e do Haiti, ex-colônia francesa que recebeu milhares de escravos africanos por quase três séculos. Tal descoberta corroborava sua hipótese de que as culturas negras em toda a América eram pontuadas de sobrevivências africanas.

Em 28 de fevereiro de 1936, Ramos escreveu a Herskovits.

Recebi com muita satisfação sua carta de 31/12/1935 e logo depois os livros e as separatas que teve a gentileza de me enviar. Sinto imenso não ter conhecido antes os seus valiosos trabalhos para citação nos meus livros. Estou lendo-os com muita atenção e proveito e conto divulgá-los o mais largamente possível para o público brasileiro. Em futuras edições dos meus livros aproveitarei o imenso material documentado e interpretativo existente nos seus trabalhos (AAR/BN, I-35, 15, 172, Rio de Janeiro, 28/2/1936. Grifos do autor).

Naquele momento, o alagoano atuava como professor de Psicologia Social na Universidade do Distrito Federal. Continuando a carta, pediu sugestões de literatura sobre psicologia e sobre religiões negras no Haiti. Também relatou as dificuldades de produção científica no Brasil.

Nós, os cientistas no Brasil, lutamos com dificuldades de toda a ordem para a realização de qualquer trabalho científico, e é para mim particularmente grato quando recebo qualquer estímulo de autoridades e amigos como o professor Herskovits (AAR/BN, I-35, 15, 172, Rio de Janeiro, 28/2/1936).

Foi o início de uma estreita cooperação intelectual que se estendeu até a morte de Ramos, em 1949. Ao todo, o Arquivo Arthur Ramos, armazenado nas dependências da Biblioteca Nacional do Rio de Janeiro, guarda 72 cartas trocadas pelos dois pesquisadores, sendo 27 escritas pelo alagoano em português e 45 escritas pelo americano, em inglês ${ }^{13}$.

\footnotetext{
${ }^{13}$ Sobre o conhecimento da nossa língua, o americano dizia: "o meu português, embora rudimentar, é adequado para ler cartas sobre assuntos com os quais estou mais ou menos familiarizado, e acho que tenho muito pouca dificuldade em entender o que você diz quando escreve" (AAR/BN, I-35, 31, 1448, Illinois, 1/10/1940). Nesse artigo, trabalhamos com a transcrição das cartas a partir das originais coletadas no Arquivo Arthur Ramos. Antônio Sérgio Guimarães também analisou a correspondência entre Arthur Ramos e Melville Herskovits. As 47 cartas estudadas pelo autor foram coletadas nos arquivos da biblioteca da Northwestern University em Evanston. Desse total, 22 cartas escritas por Arthur Ramos e 25 por Herskovits (GUIMARÃES, 2004, p.171). Guimarães dividiu a relação em três fases: "uma primeira correspondência trocada entre 1935 e 1941; uma convivência de dois meses em 1941, na Northwestern University, onde Ramos acompanha o seminário de aculturação de Herskovits; e, uma última, que começa
}

\section{GANPHLAC}

Revista Eletrônica da ANPHLAC, ISSN 1679-1061, № 27, p. 185-221, Ago./, Dez., 2019.

http://revista.anphlac.org.br 
Em 26 de março de 1936, Herskovits respondeu à inquietação de Ramos afirmando ter

um sentimento muito forte que os problemas científicos inerentes ao estudo do negro são de tal magnitude que é somente pelo contato e cooperação de todos os que estão trabalhando no campo, que qualquer resultado substancial pode ser achado. Embora, desnecessário dizer, eu saúdo esta oportunidade de continuarmos em contato um com o outro (AAR/BN, I-35, 31, 1430, Illinois, 26/3/1936).

Pela correspondência, coletada no Arquivo Arthur Ramos, tomamos conhecimento das pesquisas em andamento, viagens de estudos, livros publicados, projetos, de modo que poderíamos construir parte da trajetória acadêmica dos dois estudiosos apenas a partir da análise da troca epistolar. Além das atividades realizadas, as cartas revelam indicações de bibliografia, comunicação de congressos e seminários, informações sobre bolsas de estudo etc.

Em março de 1936, Herskovits descreveu suas pesquisas desenvolvidas no Haiti e no Suriname, em carta na qual respondia à solicitação de Ramos sobre indicações de referências bibliográficas sobre Psicologia Social. Segundo Herskovits "a melhor forma de colocá-lo em contato com o trabalho em Psicologia Social neste país é pelo trabalho de Murchison e dois volumes escritos pelo professor Kimball Young" (AAR/BN, I-35, 31, 1430, Illinois, 26/3/1936) ${ }^{14}$.

E acrescentou: "estou escrevendo para ambos pedindo que enviem cópias dos livros deles para você” (AAR/BN, I-35, 31, 1430, Illinois, 26/3/1936).

Sobre a solicitação de estudos acerca da religião dos negros no Haiti, Herskovits mencionou o etnógrafo haitiano Jean Price-Mars, autor da obra Ainsi parla l'oncle $(1928)^{15}$ e o sociólogo Justin Chrysostome Dorsainvil, autor de Vodou et nevrose (1931).

com o trabalho de campo de Herskovits no Brasil, em final de 1941, e vai até a morte de Ramos, em 1949" (GUIMARÃES, 2004, p.169).

${ }^{14}$ Herskovits se refere a MURCHISON, Carl. Social psychology, cuja primeira edição, nos Estados Unidos, é do ano de 1929 e YOUNG, Kimball. Source Book for Social Psychology (1927); Social psychology (1930). Em carta destinada a Herskovits, de 26 de maio de 1936, Ramos menciona "o recebimento da Handbook of Social Psychology, que, a seu pedido, o professor Murchison teve a gentileza de me enviar" (AAR/BN, I-35, 15, 173, Rio de Janeiro, 26/5/1936).

15 Jean Price-Mars (1876-1976), etnólogo haitiano, publicou em 1928 Ainsi parla l'oncle, no qual estuda o Vodu, os cantos e contos, as lendas e adivinhas e suas origens na África, com o objetivo de

\section{GANPHLAC}

Revista Eletrônica da ANPHLAC, ISSN 1679-1061, № 27, p. 185-221, Ago./, Dez., 2019.

http://revista.anphlac.org.br 
Sobre esses intelectuais, afirmou "que ambos ficariam mais do que felizes em enviar para você cópias de seus trabalhos se você entrar em contato com eles" (AAR/BN, I-35, 31, 1430, Illinois, 26/3/1936).

Nessa mesma correspondência, Herskovits sugeriu que em sua pesquisa acerca dos africanismos no Brasil, Ramos ultrapassasse os aspectos simplesmente culturais e questionou

\begin{abstract}
se não deveria ser de valor dar alguma atenção a outro aspecto além do religioso da cultura do negro brasileiro. Eu percebi que é mais difícil isolar os elementos africanos em tais setores do comportamento do negro no Novo Mundo do que é na vida religiosa. No entanto, eu encontrei ambos no Haiti e Guiana, já que estudantes meus recentemente descobriram nas Ilhas Virgens, Martinica e Jamaica, que há muitos aspectos na vida econômica e social as quais são tão africanas quanto às crenças religiosas (AAR/BN, I-35, 31, 1430, Illinois, 26/3/1936).
\end{abstract}

Desde o início, Herskovits se colocou no "papel de ensinar, recomendar, sugerir e, principalmente, viabilizar o treinamento profissional do colega doutor" (GUIMARÃES, 2004, p.174). Aos poucos, o brasileiro se apropriou dos conceitos e metodologias da Antropologia Cultural. Conhecimento este adquirido em grande parte por meio do intercâmbio estabelecido sobretudo com Melville Herskovits. Em carta datada de 26 de maio de 1936, Ramos confessou a Herskovits que "as suas pesquisas me esclareceram sobre muitos problemas relacionados com a vida dos negros no Novo Mundo e especialmente no Brasil”" (AAR/BN, I-35, 15, 173, Rio de Janeiro, 26/5/1936).

Nessa troca, conforme nos revela Guimarães, o antropólogo americano também incorporava conhecimentos.

Para Herskovits, o encontro com Ramos abria-lhe as portas do mundo
intelectual brasileiro e do mundo "africano" da Bahia, um dos mais bem
"conservados" das Américas. De fato, para Herskovits, Ramos representou
certamente um enorme avanço no seu projeto de pesquisa intercontinental
sobre a cultura dos povos africanos trazidos para as Amricas. Se, em 1930,
ao publicar no American Anthropologist a sua declaração sobre o "negro no
Novo Mundo", Herskovits via-se forçado a retirar os negros do Brasil de sua
escala de "africanismos no comportamento cultural" "porque [tinha] poucos
dados sobre os quais se basear", em 1955, em sua Cultural Anthropology, já

promover uma reapropriação da cultura popular haitiana, tão desprezada pelas elites. Por intermédio de Herskovits, Arthur Ramos e Jean Price-Mars trocam correspondências durante um curto período de tempo.

\title{
GANPHLAC
}

Revista Eletrônica da ANPHLAC, ISSN 1679-1061, № 27, p. 185-221, Ago./, Dez., 2019.

http://revista.anphlac.org.br 
podia colocar o Brasil na terceira posição de sua escala, logo abaixo do Suriname e do Haiti (GUIMARÃES, 2004, p.172) ${ }^{16}$.

Assim, a análise da correspondência entre os dois estudiosos revela o americano interessado em obter informações sobre os africanismos no Brasil e o alagoano dedicado a se aprofundar no estudo da Antropologia Cultural. Em 24 de fevereiro de 1937, Ramos agradeceu o recebimento do exemplar do livro Suriname Folk-lore, de autoria do Melville Herskovits juntamente a Francis Herskovits, sua esposa.

Não tenho palavras para lhe exprimir toda a minha admiração, em ler uma obra tão bem documentada, tão rica em ensinamentos, tão completa, sobre o folclore dos negros da Guiana Francesa. Pretendo dar notícia do livro aos estudiosos brasileiros, e isto é a maneira de manifestar o interesse que ele me desperta (AAR/BN, I-35, 15, 176, Rio de Janeiro, 24/2/1937).

Em carta de 18 de março de 1937, o antropólogo americano propôs união de esforços com o objetivo de ampliar os estudos sobre os africanismos nas Américas.

Eu suponho que nesses livros [referindo-se também Life in a Haitian Valley e Suriname Folk-lore] você achará correspondências com os negros brasileiros com os quais está familiarizado. Talvez no curso do tempo, com o suficiente de nós trabalhando no problema, estaremos aptos a descrever o fenômeno social das Culturas Negras no Novo Mundo (...). (AAR/BN, I-35, 31, 1436, Illinois, 18/3/1937).

A influência da produção norte-americana nos estudos de Ramos é explícita e pode ser observada com frequência em suas cartas. Em meados de 1936, publicou Introdução à Psicologia Social. Em agosto, um exemplar foi enviado a Herskovits:

Envio-lhe por esta mala meu novo livro "Introdução à Psicologia Social", obra didática que escrevi para o meu curso de Psicologia Social na universidade do Distrito Federal e onde procurei divulgar o mais possível a bibliografia/ norte-americana sobre o assunto (AAR/BN, I-35, 15, 174, Rio de Janeiro, 15/08/1936. Grifo do autor).

\footnotetext{
${ }^{16}$ Antes disso, em 1941, quando publica The myth of the negro past, Herskovits realiza uma análise das culturas afro-americanas nos Estados Unidos em comparação a outras regiões, com destaque para o Caribe, Suriname e Brasil. Era a primeira vez que o Brasil era citado pelo antropólogo americano em suas obras e isso se deve em grande parte pelo diálogo estabelecido com Arthur Ramos. A principal intenção de Herskovits com essa obra era desmontar o que ele denomina "o mito do passado negro", que sustentava que os negros teriam sido absorvidos pela tradição cultural euro-americana, abandonando por completo sua herança africana e se tornando indivíduos sem passado. Segundo Herskovits "o mito do passado Negro é um dos principais suportes do preconceito racial neste país" (HERSKOVITS, 1990, p.1).
}

\section{GANPHLAC}

Revista Eletrônica da ANPHLAC, ISSN 1679-1061, № 27, p. 185-221, Ago./, Dez., 2019. http://revista.anphlac.org.br 
Meses depois, em maio de 1937, o alagoano comunicou o avanço da obra As culturas negras do Novo Mundo, "onde lanço uma cisão do conjunto sobre os trabalhos realizados pelos pesquisadores dos Estados Unidos, Cuba, Haiti, etc.” (AAR/BN, I-35, 15, 177, Rio de Janeiro, 11/6/1937. Grifo do autor).

O reconhecimento de Arthur Ramos como pesquisador relevante das culturas africanas no Brasil é perceptível na carta escrita por Herskovits em maio de 1937, quando o antropólogo americano anunciou que estava preparando um estudante para uma pesquisa de campo entre os Iorubas da Nigéria.

Tendo em vista o fato de que muito da cultura do negro brasileiro mostra sobrevivências dos costumes iorubas, gostaria de saber se há questões levantadas por você em sua pesquisa que possam ser esclarecidas por ele em sua investigação de campo na própria África (AAR/BN, I-35, 31, 1437, Illinois, 8/5/1937).

Continuando, acrescentou:

Se você quiser me mandar uma lista de informações sobre a África que seriam de especial valor para você e para outros estudantes dos costumes negros brasileiros, eu ficaria feliz de entregá-la ao meu aluno, Sr. William Bascom. (ARR/BN, I-35, 31, 1437, Illinois, 8/5/1937)

Considerando que as sobrevivências culturais do negro brasileiro eram de origem predominantemente ioruba (nagô), Arthur Ramos manifestou imenso interesse pelo estudo das culturas originárias na África. Em resposta às solicitações de Herskovits, Ramos, em carta de 17 de agosto, formulou as seguintes questões:

1) Qual a percentagem dos povos da Nigéria que fala o iorubá? 2) Tem-se o iorubá conservado puro ou tem sofrido deformações por contatos culturais (com outras línguas vizinhas?) 3) Qual a extensão da literatura escrita (em Lagos, por exemplo) - a existência de livros de leitura em língua nagô? 4) Até que ponto as culturas religiosas se conservaram puras até hoje? 5) Os mitos iorubas conservaram-se na tradição oral até os nossos dias? 6) Será possível avaliar se houve contaminação secundária na religião e folclore com os refluxos comerciais de Lagos com o Brasil? 7) Os contos populares do ciclo da tartaruga (awon) têm origem totêmica? 8) Conservam os negros da Nigéria a memória do tráfico de escravos para o Brasil? 9) Na hipótese afirmativa, houve alguma sobrevivência deste fato na tradição oral? 10) Desejaria ter informação da coletânea de contos, provérbios e adivinhas, existentes atualmente entre os negros da Nigéria. (ARR/BN, I-35, 15, 178, Rio de Janeiro, 17/8/1937. Grifos do autor).

\section{CANPHLAC}

Revista Eletrônica da ANPHLAC, ISSN 1679-1061, № 27, p. 185-221, Ago./, Dez., 2019.

http://revista.anphlac.org.br 
Em novembro de 1937, Herskovits respondeu às questões propostas por Arthur Ramos, afirmando que tais questionamentos já haviam sido, em boa medida, estudados pelas pesquisas antropológicas realizadas nas universidades americanas. O próprio Herskovits já havia realizado pesquisa de campo na Nigéria, o que o tornava habilitado a receber as questões propostas pelo alagoano como puras e amadoras.

\begin{abstract}
Eu posso responder muitas de suas perguntas a partir de minha experiência de campo na Nigéria. O ioruba (nagô) é falado pelo grande número de povos que habita a porção sudoeste da atual colônia britânica da Nigéria. Qual é o número exato dos falantes de ioruba, eu não sei, mas não seria difícil obtê-lo nos relatórios censitários. Naturalmente, todas as línguas e todos os povos estão em contato com seus vizinhos, duvido, portanto, que o ioruba possa ser mais ou menos "puro" que qualquer outra língua. Certamente, ela não foi afetada pelo contato com os europeus de um modo perceptível. O que está escrito em nagô o foi sob influência europeia, e por iorubanos "educados". A religião continua praticamente isenta da influência europeia, ainda que, é claro, vários indivíduos nativos tenham sido convertidos ao cristianismo. A mitologia ioruba está tão viva como sempre esteve; você pode encontrar numerosos contos populares na coleção Frobenius no volume X (eu acho) da sua obra completa. A referência exata pode ser encontrada na bibliografia do nosso "Folclore do Suriname". Duvido que o contato com o Brasil tenha afetado a cultura iorubana, mas os iorubas certamente conhecem o tráfico de escravos feito pelos portugueses, no entanto não sei o quanto eles conhecem do Brasil. Se os contos da tartaruga são ou não, originariamente, totêmicos, também não posso lhe dizer, mas acho que problemas desse tipo são praticamente impossíveis de serem solucionados. (AAR/BN, I-35, 31, 1439, Illinois, 14/11/1937).
\end{abstract}

A partir dessa carta, Arthur Ramos compreendeu suas deficiências intelectuais e a necessidade de se aprofundar no campo da Antropologia. A partir de então, manifestava o desejo de realizar uma viagem de estudos aos Estados Unidos. Em 30 de maio de 1938, escreveu a Herskovits:

Sinto a necessidade inadiável de me pôr em contato direto com universitários americanos, e especialmente, com a Universidade de Northwestern e a de Chicago, no sentido de unificar os esforços metodológicos para os estudos de raça e de cultura no Novo Mundo (AAR/BN, I-35, 15, 180, Rio de Janeiro, 30/05/1938).

O alagoano lamentou ainda que as instituições culturais brasileiras não possuíssem fundos para financiar viagens longas de pesquisa. Para alcançar tal intento, seria necessária a ajuda das agências de fomento externas. Nessa mesma carta, citou o professor americano Lewis Hanke, que havia iniciado o contato entre ele e a

\title{
CANPHLAC
}

Revista Eletrônica da ANPHLAC, ISSN 1679-1061, № 27, p. 185-221, Ago./, Dez., 2019.

http://revista.anphlac.org.br 
Guggenheim. Desse modo, Ramos estabeleceu um diálogo com os responsáveis pelo programa de bolsas para brasileiros da Fundação Guggenheim.

Dr. Lewis Hanke, de Harvard, atualmente em viagem de estudos no Brasil, me fez um contato com a Guggenheim Foundation, acenando-me com a possibilidade de obter uma bolsa de estudos. Realmente eu desejaria passar um ano de estudos ao seu lado na Northwestern e talvez na Universidade de Chicago. Dei o seu nome como credencial a meu respeito. Poderia secundar meus esforços e informar a Guggenheim ou outra instituição que financiasse uma viagem de estudos? Espero um sinal de animação de sua parte, pois o meu desejo mais ardente é aproximar cada vez mais o Brasil da América do Norte, o que poderemos fazer no setor universitário (AAR/BN, I-35, 15,180, Rio de Janeiro, 30/05/1938).

Em 20 de junho de 1938, Herskovits escreveu a Ramos demonstrando imenso interesse por seu plano de viagem aos Estados Unidos. Disse da satisfação que teria em recebê-lo na Northwestern, mencionou a possibilidade de obter financiamento e comentou sobre os passos burocráticos para pleitear a bolsa de estudos da Fundação Guggenheim.

Quase três meses depois, em setembro de 1938, Arthur Ramos escreveu a Herskovits lhe informando que "nem a Guggenheim nem a Rockfeller puderam me auxiliar em meus desejos” (AAR/BN, I-35, 15, 181, Rio de Janeiro, 8/9/1938).

Em outubro, Herskovits informou a Ramos as razões para a não concessão da bolsa.

Quando estive em Nova Iorque, falei com o Sr. Moe, secretário da Fundação Guggenheim, e creio estar seguro em dizer-lhe que o único empecilho que está travando a concessão de sua bolsa (...) é a questão da extensão do programa de bolsas de estudos sul-americanos da Guggenheim para o Brasil. Devo mantê-lo a par disso, e você pode estar certo que farei tudo que estiver a meu alcance para tornar possível sua vinda para cá (AAR/BN, I-35, 31, 1.442, Illinois, 12/10/1938).

Somente no segundo semestre do ano de 1939, a Guggenheim voltaria a conceder bolsas de estudos para pesquisadores brasileiros. Ressaltou então que "pode haver uma possibilidade de arrumarmos por outras fontes para trazê-lo a esse país em uma data mais tarde". Em 17 de outubro de 1939, Herskovits comunicou a Arthur Ramos que

o programa de bolsas de estudos Guggenheim para o Brasil tornou-se um fato consumado, e eu escrevi para o Sr. Moe, o secretário da Fundação, pedindo

\section{GANPHLAC}

Revista Eletrônica da ANPHLAC, ISSN 1679-1061, № 27, p. 185-221, Ago./, Dez., 2019.

http://revista.anphlac.org.br 
que lhe enviasse o formulário de requerimento, o qual ele me informou que estava feito. Eu espero que seja possível solicitar e que nós tenhamos o grande prazer de vê-lo neste país no próximo ano. Eu ficarei, é claro, satisfeito em fazer tudo que puder para levar adiante o seu requerimento (AAR/BN, I-35, 31, 1444, Illinois, 17/10/1939) ${ }^{17}$.

Arthur Ramos candidatou-se, embora naquele momento já tivesse recebido uma oferta profissional de Lynn Smith ${ }^{18}$, chefe do Departamento de Sociologia da Universidade da Louisiana, para lecionar um curso sobre raças e relações das raças e culturas, entre 1 de fevereiro e 31 de março de 1940, naquela instituição. A carta com o convite foi escrita em 13 de outubro de 1939 e poucos dias se passaram até que Ramos respondesse ao convite efetuado por Smith:

a possibilidade que o amigo me acena de realizar um curso de raças e relações de raças em sua universidade me deixa muito honrado, mas eu só contava poder realizá-lo no ano letivo de 1940-1941 (...) conforme tínhamos conversado durante sua estadia aqui. Torna-se muito difícil para mim ausentar-me de nossa universidade no período estimado de $1^{\circ}$ de fevereiro a 31 de março, de modo que desejo perguntar-lhe se a universidade da Louisiana mantém esse convite, nas mesmas condições propostas, para o período idêntico ao primeiro no segundo semestre de 1940-1941 (outubro a janeiro ou fevereiro a maio, à sua deliberação). Se isto for possível, seria muito preferível para mim (AAR/BN, I-35, 19, 404, Rio de Janeiro, 27/10/1939).

A continuação da carta expunha a vontade que Ramos tinha de realizar uma viagem de estudos aos Estados Unidos:

No entanto, se o convite não puder ser mantido para o período de 1940-1941, eu aceitarei seu convite atual, pedindo-lhe que nesse caso, responda com a necessária urgência, a fim de que eu possa apressar os preparativos de viagem, pois teria de partir nos primeiros dias de janeiro e teria tempo suficiente para todos os preparativos do curso (AAR/BN, I-35, 19, 404, Rio de Janeiro, 27/10/1939).

\footnotetext{
${ }^{17}$ Nessa mesma carta, Herskovits comunica que fará uma viagem de estudos a Trinidad durante as férias de verão e que espera "ter resultados significativos para apontar as origens do negro do Novo Mundo e dando-nos uma noção da extensão da sobrevivência africana neste lado do Atlântico" (AAR/BN, I-35, 31,1443, Illinois, 11/4/1939).

${ }^{18}$ Thomas Lynn Smith (1903-1976), sociólogo norte-americano dedicado aos estudos sobre o mundo rural, esteve diversas vezes no Brasil desenvolvendo atividades de ensino e pesquisa entre as décadas de $1940 \mathrm{e}$ 1950.
}

\section{CANPHLAC}

Revista Eletrônica da ANPHLAC, ISSN 1679-1061, № 27, p. 185-221, Ago./, Dez., 2019.

http://revista.anphlac.org.br 
Smith reiterou o convite em carta escrita em 17 de novembro, mas para os primeiros meses de 1940. Mais uma vez, os compromissos com a universidade serviram de obstáculo para Ramos.

Infelizmente, sou forçado a comunicar-lhe que não posso ausentar-me, como julgava, no período acima indicado. A nossa Faculdade de Filosofia, onde leciono a cadeira de Antropologia teve os seus cursos prorrogados até fevereiro do próximo ano, em vista do seu funcionamento tardio, neste primeiro ano de sua fundação. Somente no ano letivo de 1940, é que este funcionamento ficará regularizado, podendo eu me ausentar, no período de outubro de 1940 a março de 1941. Julguei poder deixar um substituto para aceitar ao seu honroso e amável convite, mas a secretaria da Faculdade julga indispensável a minha presença aqui neste primeiro ano letivo. Isso me entristeceu bastante, pois o meu maior desejo era justamente conhecer a zona do deepsouth dos Estados Unidos e não havia oportunidade melhor do que a que me oferece a Universidade da Louisiana (AAR/BN, I-35, 19, 405, Rio de Janeiro 27/11/1939. Grifo do autor).

Em carta seguinte, Smith comunicou que a Universidade da Louisiana aceitou transferir o curso que Ramos ministraria para o período de 9 de setembro de 1940 a 25 de janeiro de 1941. Em 5 de agosto, Ramos comunicou a Smith que embarcaria no

próximo dia 24 de agosto, pelo Delmundo, devendo estar em New Orleans a 11 de setembro. Não foi possível conseguir passagem no dia 8 , e assim, chegaremos [ele e sua esposa, Dona Luiza] dois dias além do início do prazo fixado para o meu curso (AAR/BN, I- 35, 19, 409, Rio de Janeiro, 5/8/1940. Grifo do autor).

Nessa mesma carta, Ramos expôs o desejo de esticar sua estadia nos Estados Unidos, dizendo que pretendia visitar o norte do país após o término dos cursos ministrados na Louisiana.

Em agosto de 1940, antes mesmo da viagem, Ramos escreveu a Herskovits manifestando interesse em permanecer nos Estados Unidos e realizar estudos na Universidade de Northwestern. Segundo Ramos,

o meu curso sobre Raças e Culturas no Brasil na Universidade da Louisiana durará de 9 de setembro a 31 de Janeiro. Pretendo seguir logo depois imediatamente para o norte e visitar Chicago e Evanston, com o fim especial de conhecer a universidade de Chicago e a Northwestern University onde terei o prazer de conhecê-lo pessoalmente. Antecipadamente lhe agradeço quaisquer arranjos ou facilidades para uma estadia de três meses de estudos em sua Universidade. Obtive da Guggenheim Foundation apenas 25\% da quantia destinada aos fellowships para estudiosos do Brasil, em vista do estipêndio que vou receber da Louisiana State University (AAR/BN, I-35,15, 185, Rio de Janeiro, 1/8/1940).

\section{GANPHLAC}

Revista Eletrônica da ANPHLAC, ISSN 1679-1061, № 27, p. 185-221, Ago./, Dez., 2019.

http://revista.anphlac.org.br 
Em 8 de setembro de 1940, Herskovits saudou a chegada de Arthur Ramos aos Estados Unidos. "Nós estamos ansiosos para tê-los em Evanston o mais cedo, e eu espero que possamos fazer uso da sua disponibilidade enquanto estiver aqui" (AAR/BN, I-35, 31, 1.447, Illinois, 08/09/1940). Em seguida, convidou-o para dirigir um seminário sobre raças e povos do Brasil, durante o segundo semestre de 1941, na University of Northwestern. Para tanto, Melville Herskovits lhe ofereceu a quantia de \$500 como honorário pelo curso. Sobre o valor, questionou se

a quantia de $\$ 500$ seria apropriada como honorário, que, creio, será satisfatória como suplemento de sua bolsa da Guggenheim que, eu posso entender bem, não é muito em vista dos consideráveis gastos de viagem e custos de vida que você manterá (AAR/BN, I-35, 31, 1.447, Illinois, 8/9/1940).

Nessa mesma ocasião, Herskovits convidou Ramos a participar do encontro anual da American Anthropological Association, que aconteceria na Filadélfia durante o recesso natalino de 1940.

Eu sei que é um longo caminho da Louisiana para a Costa Leste, mas isto possibilitaria, a você, reunir-se com todos e, para nós, combinar alguns debates sobre o campo de estudos comparativos sobre o negro (AAR/BN, I-35, 31, 1.447, Illinois, 8/9/1940).

Após uma semana, Ramos respondeu que

sua carta de 8 deste mês já estava à minha espera na L.S.U. e tive um grande prazer em receber os seus votos de boas-vindas. Fiquei muito satisfeito com a perspectiva que me oferece, do convite para dar um seminário sobre raças e povos do Brasil no segundo semestre com o honorário de $\$ 500$. Seria para mim de uma grande ajuda e, ao mesmo tempo, uma magnífica oportunidade de haver um contato mais íntimo com os estudantes da sua universidade interessados naqueles assuntos. Creio que poderei estar aí nos primeiros dias de fevereiro, fazendo um curso de três meses, até o começo de maio (AAR/BN, I-35, 15, 186, Louisiana, 17/9/1940).

Naquela ocasião, Arthur Ramos já estava em Nova Orleans e já havia começado seu curso na Louisiana State University. Suas primeiras impressões foram descritas em carta dirigida a Herskovits apenas um mês após sua chegada a Baton Rouge. Nela, Ramos declarou estar apreciando muito a estadia e que pretendia aproveitar o "tempo disponível para estudar os negros da região" (AAR/BN, I-35, 15, 186, Louisiana, 17/9/1940).

\section{GANPHLAC}

Revista Eletrônica da ANPHLAC, ISSN 1679-1061, № 27, p. 185-221, Ago./, Dez., 2019.

http://revista.anphlac.org.br 
Não só os estudantes como (os) professores estão muito interessados por tudo quanto tenho dito sobre os problemas de raças e de culturas no Brasil. Tenho aproveitado as horas vagas para estudar e observar a vida do negro nas plantações da Louisiana e em outros atos da sua vida social, do ponto de vista antropológico e sociológico, e será excelente trocarmos depois nossas impressões (AAR/BN, I-35, 15, 186, Louisiana, 17/9/1940) ${ }^{19}$.

Nessa mesma carta, Ramos lamentou não poder comparecer à reunião anual da American Anthropological Association, na Filadélfia, durante recesso do Natal. "Creio que a longa distância e as minhas obrigações aqui não me permitirão ausentar-me nesse período" (AAR/BN, I-35, 15, 186, Louisiana, 17/09/1940). Terminou a carta pedindo desculpas

por lhe escrever em português. Embora esteja me adiantando visivelmente no inglês, posso, desta maneira, exprimir melhor e mais rapidamente o meu pensamento. As minhas aulas estão redigidas em inglês e eu estou apto a discutir e debater com os alunos também em inglês. Em poucos meses mais estarei, porém, apto a me exprimir corretamente na sua língua (AAR/BN, I-35, 15, 186, Louisiana, 17/09/1940).

\section{Sobre essa questão, Herskovits afirmou saber o quanto}

é difícil expressar-se escrevendo em uma língua estranha, e espero que você não se sinta obrigado a escrever-me em inglês. $\mathrm{O}$ meu português, embora rudimentar, é adequado para ler cartas sobre assuntos com os quais estou mais ou menos familiarizado, e acho que tenho muito pouca dificuldade em entender o que você diz quando escreve. Então, espero que você faça como for de sua conveniência nesta questão (AAR/BN, I-35, 31, 1448, Illinois, $1 / 10 / 1940)$.

Herskovits voltou a falar da importância da presença de Ramos durante a reunião da Anthropological Association, em Filadélfia, durante o recesso de Natal. Dessa vez, Ramos justificou sua recusa devido ao "alto custo de vida do norte" e condiciona sua ida a alguma verba complementar.

Quanto à reunião da Anthropological Association, em Philadelphia, durante as férias de Natal seria realmente muito interessante se pudesse conseguir qualquer auxílio para as despesas de viagem, tendo em vista a grande

19 Conforme salienta Olívia Maria da Cunha, "Ramos preferiu manter o silêncio, ainda que seus interlocutores lhe pedissem comentários e até pesquisas sobre a 'situação dos negros no Sul'. Ramos, ao contrário, referiu-se vagamente a aspectos ligados ao 'folclore negro na Louisiana' para abordar o 'problema das raças' no Brasil. Ramos passou alguns meses de sua estada nos EUA numa típica cidade do Sul sob o Jim Crow, entretanto não mencionou a existência de linchamentos, high schools e colleges segregados. Nem assinalou a permanente tensão racial em Chicago, a timidez dos campi liberais e supostamente dessegregados nas cidades do Norte" (CUNHA, 1999, p.89).

\section{GANPHLAC}

Revista Eletrônica da ANPHLAC, ISSN 1679-1061, № 27, p. 185-221, Ago./, Dez., 2019.

http://revista.anphlac.org.br 
distância daqui lá. Só nestas condições, eu poderia ter a oportunidade de fazer, que seria impossível de outro modo, em vista do alto custo de vida no Norte (Carta de Ramos a Herskovits, 12/10/1940, GUIMARÃES, 2004).

Buscando possibilitar a participação de Ramos no encontro da Anthropological Association, Herskovits escreveu a Henry Moe, secretário da Fundação Guggenheim, solicitando, sem êxito, recursos para o financiamento da viagem até a Filadélfia. Antônio Sérgio Guimarães teve acesso à carta enviada por Henry Moe a Herskovits:

Em resposta a sua carta de 17 de outubro sobre o Dr. Ramos, quero lhe transmitir uma informação confidencial. Quando examinei a sua situação financeira na primavera passada, descobri que ele iria receber US $\$ 4,000.00$ da L.S.U. por suas aulas, o que é um pagamento alto para professores neste país, segundo qualquer padrão, tendo em vista a brevidade do tempo que ele dedicaria. Pareceu-me claro que com o estipêndio da L.S.U. ele não necessitaria de ajuda financeira suplementar para passar um par de meses extra com você. No entanto, levando em consideração sua capacidade, o Comitê de seleção me autorizou a conceder um pequeno estipêndio se ele fizesse um pedido bem fundamentado. Em correspondência subsequente com Dr. Ramos me parece que ele precisava de dinheiro para suas passagens oceânicas e, por isso, concedi US\$ 500.00 adicionais, que correspondia ao limite que eu estava autorizado a conceder. Se você acha que pode fundamentar um pedido de mais de US\$ 4,500.00, eu gostaria de ouvir tal justificativa. E tentaria também conseguir algo (apud GUIMARÃES, 2004, p.180).

Além das aulas como Special Lecture in Sociology na Louisiana State University, Arthur Ramos proferiu conferências nas universidades de Stanford, Yale, Howard, California, Berkeley, Utah e outras. Além disso, a Northwestern University (Illinois) o nomeou Honorary Research Associate in Anthropology. Antônio Sérgio Guimarães nos lembra que

além do Leste, Arthur Ramos aproveitou a sua estadia nos Estados Unidos, para outros contatos profissionais importantes no Meio-Oeste. O primeiro desses contatos foi com Stuart Chapin, do Departamento de Sociologia da University of Minnesota, feito com a intermediação primeira de Lynn Smith (GUIMARÃES, 2004, p.185).

Em missiva escrita em 6 de fevereiro, Francis Stuart Chapin ${ }^{20}$ se dirigiu a Melville Herskovits para, por seu intermédio, convidar Arthur Ramos para palestrar

\footnotetext{
${ }^{20}$ Francis Stuart Chapin (1888-1974) foi um sociólogo e educador americano, professor de sociologia na Universidade de Minnesota de 1922 a 1953.
}

\section{CANPHLAC}

Revista Eletrônica da ANPHLAC, ISSN 1679-1061, № 27, p. 185-221, Ago./, Dez., 2019.

http://revista.anphlac.org.br 
duas conferências em Minnesota no final daquele mês. No dia 19 de fevereiro, Ramos respondeu afirmativamente ao convite por meio de carta enviada a Chapin.

Meu caro Dr. Chapin

Recebi do Dr. Herskovits sua carta de 6 de fevereiro, convidando-me, pela sugestão do professor T. Lynn Smith, para visitar a universidade de Minnesota na segunda, dia 27 de fevereiro e terça, dia 28 de fevereiro. Eu aceito com imenso prazer a honra de ser convidado para fazer conferências na sua universidade. No entanto, como meu programa na Northwestern University é muito próximo e estou participando da reunião do seminário do Dr. Herskovits que se reúne toda terça-feira, seria preferível se eu pudesse ir um pouco mais tarde a Minnesota University, talvez no começo de março numa quinta ou sexta-feira, como o Dr. Herskovits sugeriu (AAR/BN, I-35, 14, 93, Louisiana, 19/2/1941).

Diante do apontado por Arthur Ramos, as conferências em Minnesota foram remarcadas paras os dias 3 e 4 de abril. Em 25 de fevereiro de 1941, Chapin enviou para Ramos a programação para esses dois dias.

Quinta-feira, 3 de abril - um jantar às 18 horas e Mesa Redonda sobre Relações Internacionais, um grupo de talvez quarenta membros do corpo docente. Sugerimos que o assunto desta palestra seja "Problemas raciais na América do Sul". A segunda palestra seria sexta-feira à tarde às $15 \mathrm{~h} 30$ sobre o tema "As raças e culturas do Brasil" (AAR/BN, I-35, 26, 1.008, Minneapolis, 25/2/1941).

Além das palestras, estava previsto um almoço com membros dos departamentos de sociologia e antropologia e outros estudiosos que visitaram países sul-americanos a fim de estreitarem relações (AAR/BN, I-35, 26, 1.011, Minneapolis, 24/3/1941). De Minneapolis, Ramos seguiu para Chicago para participar do congresso da American Association of Physical Anthropologists, realizado entre os dias 7 e 8 de abril de 1941. De Chicago foi para Nova Iorque.

Em carta datada de 11 de abril de 1941, Herskovits traçou um roteiro para o alagoano a partir de Nova Iorque. Vejamos o percurso:

Depois de instalado em seu hotel, sugiro que vá à Universidade Columbia, Departamento de Antropologia, e se apresente a Linton. Lá você saberá quando o Dr. Boas estará presente e a melhor maneira de encontrá-lo.

Ruth Benedict, Klineberge Herzog deverão estar no mesmo prédio e qualquer um deles poderá lhe pôr em contato com o Dr. Elsie Clews Parsons, Herald Courlander, Du Bois, Kerdiner e Margaret Mead.

\section{CANPHLAC}

Revista Eletrônica da ANPHLAC, ISSN 1679-1061, № 27, p. 185-221, Ago./, Dez., 2019.

http://revista.anphlac.org.br 
No Museu Americano de História Natural, você poderá procurar Dr. Wissler, lá também estão vários excelentes arqueólogos, particularmente N. C. Nelson e George Valliant, e a assistente de Wissler, senhorita Bella Weitzner, a quem você deveria procurar se Wissler não estiver, será igualmente muito útil.

No Social Science Research Council, 230 Park Avenue, em Nova Iorque, você encontrará Donald Young e Moseley, ambos os quais você encontrou aqui. O escritório da Fundação Guggenheim, tal como o da S.S.R.C., é muito próximo do seu hotel, e lá você poderá procurar o Sr. Moe. (AAR/BN, I-35,31, 1454, Illinois, 11/4/1941).

Herskovits expandiu ainda o roteiro para outras cidades, as quais Ramos planejava visitar:

Na Filadélfia, você encontrará o University Museum, importante pelos seus materiais africanos e pela significativa efetivação de antropólogos. $\mathrm{Na}$ Universidade da Pennsylvania, você encontrará A. I. Hallowell, cujo trabalho de campo das relações entre personalidade e cultura é excelente; Frank Speck, o especialista em Índia, e Hans Wieschhoff, o especialista em África. No museu propriamente, você deveria contactar J. Alden, especialista em arqueologia da América Central.

Em Washington, obviamente você será cuidado pelo povo da Universidade Howard, como você disse; no Departamento de Estado, Pattee, e na Biblioteca do Congresso, Hanke se encarregarão de fazer com que você encontre todo mundo. Será muito bem recebido, estou certo, se você procurar Dr. Waldo G. Leland no American Council of Learnead Societies. Tanto Hanke, quanto Pattee fariam isso com prazer. Quando você se encontrar com Thompson, chefe da Divisão de Cooperação Intelectual do Departamento de Estado, poderia perguntar a ele que trem tomará para Chicago para assistir à conferência em Evanston do S.S.R.C. Estou certo de que você achará que valerá a pena se, por acaso, vocês dois viessem no mesmo trem.

Acho também que você verá Concha Romero James em Washington (AAR/BN, I-35, 31, 1454, Illinois, 11/04/1941).

Todavia, a intervenção mais importante de Ramos nos Estados Unidos se deu na Universidade de Northwestern, em Evanston, no estado de Illinois, onde permaneceu em convívio diário com Herskovits (GUIMARÃES, 2004).

Conforme carta escrita por Herskovits em 7 de fevereiro de 1941, o primeiro evento de Ramos na Northwestern University seria uma palestra intitulada The race problem in Brazil, ministrada em 19 de abril daquele ano. A palestra abriria um evento, organizado pelos alunos, dedicado às relações interraciais. Segundo Herskovits,

os alunos levantaram fundos para cobrir o custo deste evento e para suprir um honorário de \$50 para os principais palestrantes, o que eu creio que será satisfatório para você. Isso dará uma oportunidade para apresentar suas pesquisas sobre relações de raça no Brasil para um grupo de mentes jovens e zelosas (AAR/BN, I-35, 31, 1433, Illinois, 7/2/1941).

\section{CANPHLAC}

Revista Eletrônica da ANPHLAC, ISSN 1679-1061, № 27, p. 185-221, Ago./, Dez., 2019.

http://revista.anphlac.org.br 
O período que passou nos Estados Unidos transformou Arthur Ramos em um cientista social conhecedor das teorias antropológicas discutidas nas universidades americanas. Essa experiência também possibilitou que ele compartilhasse com aquelas instituições os objetos e os resultados de suas pesquisas referentes à história e cultura afro-brasileira e o problema do negro no Brasil. De acordo com Guimarães,

Arthur Ramos chegou aos Estados Unidos como um especialista, um
africanista brasileiro. A sua estadia em Evanston, no seminário sobre
aculturação, dirigido por Herskovits, teve, na prática a função de introduzi-lo
nas técnicas da moderna Antropologia Cultural, enquanto o curso ministrado
na Louisiana e as suas conferências e palestras no exterior serviram aos fins
de legitimação e fama (GUIMARÃES, 2004, p.185).

Arthur Ramos se tornava o mais importante antropólogo brasileiro dos anos de 1940, porém, a estadia nos EUA avivou seu olhar para a desigualdade social baseada na cor da pele presente no cotidiano dos negros tanto na sociedade norte-americana quanto na brasileira. Voltou ao Brasil convencido da necessidade de fazer de seu conhecimento uma arma contra as injustiças político-sociais. Tornara-se clara, então, sua opção pela Antropologia Aplicada. Ramos se converteu em um ativista da luta antirracista e pródemocrática ${ }^{21}$.

\section{Arthur Ramos e Melville Herskovits: divergências de ideias}

Em setembro de 1941, Melville Herskovits desembarcou no Brasil com o objetivo de realizar estudos antropológicos sobre o negro brasileiro. Sua viagem se iniciou pelo Rio de Janeiro, onde residiu por pouco mais de dois meses. Naquele período, desfrutou da companhia de Arthur Ramos e se inteirou do meio universitário e intelectual brasileiro. Seguiu para a Bahia em novembro de 1941, levando as cartas de apresentação escritas por Arthur Ramos. Lá permaneceu até maio de 1942, quando

\footnotetext{
${ }^{21}$ Embora atuante nas discussões acerca da importância da Antropologia para a luta antirracista, Ramos, como demonstram suas "notas de pesquisa" armazenadas no Arquivo Arthur Ramos, continuou durante os anos 1940 suas investigações sobre a vida e religiosidade dos pobres no Rio de Janeiro.
}

\section{GANPHLAC}

Revista Eletrônica da ANPHLAC, ISSN 1679-1061, № 27, p. 185-221, Ago./, Dez., 2019.

http://revista.anphlac.org.br 
embarcou para Recife para quatro semanas de pesquisa. Em junho retornou ao Rio de Janeiro e seguiu em julho para Porto Alegre, onde realizou pesquisas sobre o batuque e o papel dos cultos aos antepassados nas relações familiares. Retornou aos Estados Unidos em agosto daquele ano. Em 1942, Arthur Ramos fundou a Sociedade Brasileira de Antropologia e Etnologia (SBAE). À frente da SBAE, Ramos encabeçou um manifesto dos antropólogos brasileiros dirigido ao governo, no qual se colocavam "a serviço" da luta antifascista. De acordo com o manifesto,

A história do racismo (...) teve os seus precursores e os seus codificadores, aqueles que criaram toda uma teoria das raças baseadas em termos biológicos exclusivos, com suas categorias de superioridade e inferioridade, e o direito consequente que teriam as "raças superiores" de dominarem às outras, chamadas "raças inferiores" de povos escravos e dominados.

Nunca, porém, essas distorções da Antropologia tiveram uma expressão mais intensa e ativa do que com os técnicos germânicos do racismo que elaboraram o arcabouço biológico da filosofia nazista da vida e da cultura. Em nome da fórmula Blut und Boden - sangue e território - as maiores atrocidades têm sido cometidas à base das falsas noções de superioridade do sangue nórdico e dos direitos de conquista do espaço vital. (...)

A farsa já foi desmascarada pelos argumentos científicos dos antropólogos do mundo inteiro, que não se dobram as injunções do nazi-fascismo. Os termos "raça" e "cultura" foram definidos com exatidão. Ficou comprovado que não podemos erguer categorias de desigualdades raciais, em base puramente biológica. As desigualdades humanas são produtos dos seus meios de sociedade e de cultura, são contingências de sua totalidade histórica e cultural.

\section{O Manifesto destacava que}

O Brasil é uma nação formada dos elementos étnicos mais heterogêneos. Aqui se misturaram povos de procedências étnicas indígenas, europeias e africanas, num tal ambiente de liberalidade e ausência de restrições legais à miscigenação que o Brasil se tornou a terra ideal para a vida em comum de povos das procedências étnicas mais diversas. Esse grande "laboratório de civilização" como já foi chamada a nossa terra, apresentou a solução mais científica e mais humana para o problema, tão agudo entre outros povos, da mistura de raças e de culturas. (...)

Esta filosofia brasileira, no tratamento das raças, é a maior arma que podemos oferecer contra a monstruosa filosofia nazista, em nome da raça, trucida e saqueia, nas tentativas de dominação do mundo (...) (Fonte: Arquivo Gustavo Capanema, série correspondentes. Carta de Artur Ramos a Gustavo Capanema enviando o texto do Manifesto da Sociedade Brasileira de Antropologia e Etnologia, que critica o nazismo alemão. Rio de Janeiro, $11 / 09 / 1942$

Disponível

em http://docvirt.com/docreader.net/DocReader.aspx?bib=ARQ_GC_B\&PagFis $=8396 \&$ Pesq $=$ ) .

\section{CANPHLAC}

Revista Eletrônica da ANPHLAC, ISSN 1679-1061, № 27, p. 185-221, Ago./, Dez., 2019.

http://revista.anphlac.org.br 
O manifesto deixou claro que a Antropologia de todo o mundo já havia derrubado cientificamente a dicotomia superioridade/inferioridade entre raças, exprimindo que as diferenças humanas são "contingências de sua totalidade histórica e cultural".

A SBAE acreditava que o Brasil poderia fornecer um exemplo eloquente da possibilidade de uma vida comum entre diversas etnias e de uma intensa miscigenação sem prejuízo de quaisquer capacidades e habilidades civilizacionais. Para a SBAE, o Brasil seria um grande "laboratório de civilização" pronto a mostrar ao mundo que sua história erigiria uma nova perspectiva em termos raciais e culturais.

Nesse momento, Ramos compreendia que o culturalismo era insuficiente para as transformações sociais às quais almejava, distanciando-se paulatinamente de Herskovits (um acadêmico demasiadamente centrado nas pesquisas ligadas aos africanismos no Novo Mundo) para dedicar-se à Antropologia Aplicada. Embora Ramos tenha se preocupado em apresentar o antropólogo americano para intelectuais brasileiros, capazes de auxiliá-lo em sua jornada no Brasil, a relação entre os dois naquele momento não era de proximidade. Segundo Guimarães, citando Stocking Jr. (2002):

Toda a antropologia americana, não apenas os boasianos, volta-se para o esforço de guerra em 1941. Herskovits tende a isolar-se politicamente ainda mais porque também o seu culturalismo, ao ressaltar as raízes africanas da cultura negra no Novo Mundo, deixa de ser politicamente atraente para as lideranças negras americanas, mais voltadas para a integração dos negros na sociedade americana. O contrário se passa com Ramos que, em seu retorno ao Brasil, volta-se cada vez mais para a antropologia aplicada (GUIMARÃES, 2004, p. 184).

Possivelmente resida aí a causa do afastamento entre os intelectuais, uma vez que Arthur Ramos já não era mais apenas um pesquisador dos africanismos presentes no Brasil, dedicando-se plenamente aos assuntos políticos. A partir de 1943, as cartas trocadas entre os dois intelectuais ocorreram esporadicamente. Em 1943, Herskovits escreveu a Ramos a fim de comunicá-lo sobre a ideia de criar uma Inter-American Society of negro studies. A intenção era reunir em torno de uma sociedade estudiosos das Américas no campo dos Estudos do Negro, cujo presidente seria Herskovits. Entre as iniciativas do grupo estava a criação de uma revista chamada Afro-América, que

\section{CANPHLAC}

Revista Eletrônica da ANPHLAC, ISSN 1679-1061, № 27, p. 185-221, Ago./, Dez., 2019.

http://revista.anphlac.org.br 
deveria conter artigos em francês, português, espanhol (cujo editorial ficaria sob responsabilidade do professor Fernando Ortiz em Havana). Em 30 de julho de 1943, Ramos respondeu à chamada afirmando estar grato pela lembrança do seu nome e que a sociedade projetada teria sua total cooperação (AAR/BN, I-35,15,193, Carta a Herskovits, Rio de Janeiro, 30/6/1943). Infelizmente o projeto não prosperou. Em 1944, a discussão entre os dois intelectuais girou em torno da tentativa em vão de editar no Brasil a obra Acculturation, de Herskovits, publicada em 1938.

Entre agosto de 1945 e dezembro de 1947, há um longo intervalo sem correspondência entre eles. A partir de então, em seu esforço para incluir a Antropologia brasileira no mundo democrático do pós-guerra, Arthur Ramos contou com o apoio teórico de um crítico feroz do culturalismo de Herskovits: Franz Frazier que o ajudaria na definição da política a ser adotada pelo Departamento de Ciências Sociais da UNESCO com respeito ao racismo (MAIO, 1997).

O engajamento de Arthur Ramos no combate ao racismo e o reconhecimento da sua intensa produção dedicada à questão negra na sociedade brasileira e à Antropologia no Brasil basearam o convite, em 1949, para assumir a direção do Departamento de Ciências Sociais da Unesco ${ }^{22}$. Conforme destaca Luitgarde Barros, Ramos

foi convocado para constituir, com eminentes figuras intelectuais como Jean Piaget, Julien Huxley, Otto Klineberg, Bertrand Russel e Maria Montessori, uma equipe de cientistas que se propunham utilizar a ciência como instrumento de reconstrução do mundo dilacerado pela guerra, condenando e combatendo as concepções que, segundo eles, tinham provocado a hecatombe (BARROS, 2000, p. 139).

Convite aceito, Arthur Ramos se tornou o responsável pela elaboração de um grande projeto de estudos das relações raciais no Brasil, financiado por aquela agência.

\footnotetext{
22 Naquele momento, devido à persistência do racismo no pós Segunda Guerra, a Unesco via a necessidade urgente de pensar políticas de incorporação de determinados estratos sociais marginalizados à modernidade. Marcos Maio ressalta que "no final dos anos 1940, a Unesco procurou, em face da persistência da intolerância racial nos EUA e na África do Sul, do processo de descolonização asiático e africano e do surgimento da Guerra Fria, tornar inteligíveis os fatores que, em nome da raça, levaram aos resultados catastróficos da II Guerra Mundial. Foi nesse contexto que houve, simultaneamente, a emergência de uma crítica radical ao determinismo biológico e a busca de evidências científicas - a partir de uma experiência social julgada bem-sucedida em matéria racial -, que servissem de contraponto à ideologia das hierarquias raciais, em suma, ao racismo" (MAIO, 1999, p. 30).
}

\section{GANPHLAC}

Revista Eletrônica da ANPHLAC, ISSN 1679-1061, № 27, p. 185-221, Ago./, Dez., 2019.

http://revista.anphlac.org.br 
Já em Paris, Ramos recebeu a última carta de Herskovits, na qual o americano o cumprimentou pela direção do Departamento de Ciências Sociais da Unesco e lhe desejou sucesso ${ }^{23}$. Nessa mesma carta, Herskovits apresentou dois alunos, Sr. e Sra. Robert Lystad, que estavam de passagem por Paris a caminho de uma viagem de campo ao Oeste da África (AAR/BN, I-35, 31, 1.473, Evanston, 20/08/1949).

\section{Considerações finais}

Médico formado em 1926 pela Faculdade de Medicina da Bahia, Arthur Ramos tomou conhecimento, desde seus primeiros estudos, da obra de Nina Rodrigues, um dos primeiros intelectuais a escrever sobre os negros no Brasil. Ainda que vinculado às teorias de sua época - com reflexões acerca da raça como origem de problemas sociais e a ideia de inferioridade física calcada em fundamentos biológicos e em estudos de antropologia criminal -, Nina Rodrigues lançou luz sobre um objeto até então pouco observado nas pesquisas científicas no Brasil: a questão do negro. Sua importância reside mais na escolha do tema, socialmente controverso no Brasil, e do uso de uma parte da antropologia para tratá-lo que nos resultados determinísticos a que já houvera chegado os pensadores europeus, como Lombroso, Gobineau etc.

Arthur Ramos deveu muito a Nina Rodrigues por seu convencimento de que a questão racial no Brasil seria central para a compreensão de nossos problemas, entretanto, logo sugeriu um viés psicanalítico e da psicologia social para estudar o

\footnotetext{
${ }^{23}$ No início de agosto, Ramos se muda para Paris, onde permaneceria por pouco mais de dois meses, pois que, surpreendentemente, falece na noite de 31 de outubro. No curto espaço de tempo em que esteve no comando do Departamento de Ciências Sociais, "Arthur Ramos organizou um fórum para debater o estatuto científico do conceito de raça. Dentro da programação de combate à discriminação racial aprovada pela quarta sessão da Conferência Geral da Unesco, em setembro de 1949, o antropólogo informava aos futuros participantes do encontro que seu objetivo era "reunir um comitê de especialistas em Antropologia Física, em Sociologia, em Psicologia Social e em Etnologia para formular uma definição preliminar das raças do ponto de vista interdisciplinar. Este será o ponto de partida indispensável para uma futura ação da Unesco em 1950" (MAIO, 1999, p.29).
}

\section{GANPHLAC}

Revista Eletrônica da ANPHLAC, ISSN 1679-1061, № 27, p. 185-221, Ago./, Dez., 2019. http://revista.anphlac.org.br 
assunto. A noção de "alma primitiva", com "heranças pré-lógicas" de compreensão da realidade, dificultaria a inserção do negro em uma civilização ocidental branca mais “evoluída". Já aí, tem-se o entendimento de uma causa cultural para a "inferioridade" do negro em nossa sociedade. Contudo, ainda se mantinha, apesar de não explícita, a consideração de uma hierarquia, não mais a partir da raça, mas por questões culturais.

A mudança na trajetória intelectual foi construída com o apoio essencial de Melville Herskovits. Com ele conheceu o culturalismo e passou a usar os conceitos próprios dessa metodologia: "contatos culturais", "apropriação", "assimilação cultural”, "aculturação", etc. Por meio do culturalismo antropológico, Ramos passou do engessado esquema de hierarquias civilizacionais - no qual se tem um objetivo final que seria, através da educação, levar os negros para o topo desta escada, onde lá os esperam os brancos "evoluídos" - para um orgânico processo de assimilação cultural que traria os negros para dentro de uma sociedade branca com algumas contribuições pontuais, mas dissipando, de maneira geral, a cultura africana.

O pós-guerra trouxe nova luz sobre o problema racial, encaminhando os estudiosos para a necessidade de combate ao racismo e respeito às diferenças; assim, Ramos passou a advogar, pela Antropologia Aplicada, novas formas de estudar as relações raciais no Brasil e parte para a defesa da "democracia racial", sendo o Brasil um exemplo de nova civilização para o mundo.

Paralelamente a essas reviravoltas no pensamento do alagoano, seu amadurecimento profissional o tornava um militante político e da institucionalização das Ciências Sociais no país. As conversas, os contatos e diálogos presentes nas cartas revelam a vinculação do antropólogo brasileiro com um complexo "sistema intelectual internacional" e sua fecunda produção nos anos 30 e 40 (sobretudo os Estudos AfroAmericanos), na qual o rigor acadêmico, a preocupação política e o combate ao racismo inspiraram a criação dos Estudos Afro-Brasileiros, que fortaleceram a antropologia como disciplina viável para pensar a questão do negro no Brasil.

\section{CANPHLAC}

Revista Eletrônica da ANPHLAC, ISSN 1679-1061, № 27, p. 185-221, Ago./, Dez., 2019.

http://revista.anphlac.org.br 


\section{Referências Bibliográficas}

ALMEIDA, Maria Hermínia Tavares de. Dilemas da institucionalização das Ciências Sociais no Rio de Janeiro. In MICELI, Sergio. (org.) História das Ciências Sociais no Brasil. São Paulo: Vértice / Revista dos Tribunais / Idesp, 1989.

BARROS, Luitgarde O. C. Arthur Ramos e as dinâmicas sociais do seu tempo. Maceió: EdUFAL, 2000.

Introdução. In FAILLACE, Vera Lúcia Miranda (org). Arquivo Arthur Ramos: Inventário Analítico. Rio de Janeiro: Fundação Biblioteca Nacional, 2004.

BARROS, Luitgarde O. C., VALVERDE, Orlando \& CUNHA, Waldir da. Mesa-redonda. Anais da Biblioteca Nacional, Rio de Janeiro, n. 119, pp.125-157, 1999.

CAMPOS, Maria José. Arthur Ramos, luz e sombra na antropologia brasileira: uma versão da democracia racial no Brasil nas décadas de 1930, 1940. Rio de Janeiro: Edições Biblioteca Nacional, 2004.

CORRÊA, Mariza. As ilusões da liberdade: a escola Nina Rodrigues e a Antropologia no Brasil. Bragança Paulista: Edusf, 1998.

Cartas Marcadas: Arthur Ramos a o Campo das Relações Raciais no Final dos Anos 1930. Anais da Biblioteca Nacional, Rio de Janeiro, n.119, pp. 35-58, 1999.

COSTA PINTO, L. A. Arthur Ramos. In TEIXEIRA, Anísio et al. Arthur Ramos. Rio de Janeiro: Ministério da Educação e Saúde, 1952.

CUNHA, Olívia Maria Gomes da. Minha adorável lavadeira: uma etnografia mínima em torno do Edifício Tupi. Anais da Biblioteca Nacional, Rio de Janeiro, n. 119, pp. 59-107, 1999.

DANTAS, Beatriz Góis. Vovó nagô e papai branco: usos e abusos da África no Brasil. Rio de Janeiro: Graal, 1988.

DUARTE, Luiz Fernando. Arthur Ramos, antropologia e psicanálise no Brasil. Anais da Biblioteca Nacional, Rio de Janeiro, n. 119, pp. 11-28, 1999.

FAILlACE, Vera Lúcia Miranda (org). Arquivo Arthur Ramos: Inventário Analítico. Rio de Janeiro: Fundação Biblioteca Nacional, 2004.

\section{CANPHLAC}

Revista Eletrônica da ANPHLAC, ISSN 1679-1061, № 27, p. 185-221, Ago./, Dez., 2019.

http://revista.anphlac.org.br 
GOMES, Angela de Castro. Em família: a correspondência entre Oliveira Lima e Gilberto Freyre. In GOMES, Angela de Castro (org). Escrita de si, escrita da história. Rio de Janeiro: Editora da Fundação Getúlio Vargas, 2004.

GUIMARÃES, Antônio Sérgio A. Africanismo e democracia racial: a correspondência entre Herskovits e Arthur Ramos (1935-1949). [s.l.]: [s.n.], [s.d.]. Disponível em: https://edisciplinas.usp.br/pluginfile.php/271096/mod resource/content/1/Africanismo\%20e\%2 0democracia\%20racial.pdf.

Intelectuais negros e formas de integração nacional. Estudos Avançados, São Paulo, v.18, n. 50, pp.271-284, 2004.

Comentários à correspondência entre Melville Herskovits e Arthur Ramos (19351941). In: PEIXOTO, Fernanda Arêas; PONTES, Heloisa; SCHWARCZ, Lilia Moritz (Org.). Antropologia, história, experiências. Belo Horizonte: Editora UFMG, 2004, pp. 169-198.

GUTMAN, Guilherme. Raça e psicanálise no Brasil. O ponto de origem: Arthur Ramos. Revista Latino-americana de Psicopatologia Fundamental, São Paulo, v. 10, n. 4, pp. 711-728, dez. 2007.

HERSKOVITS, Melville J. The myth of the negro past. Boston: Beacon Press, 1990. . Pesquisas etnológicas na Bahia, Museu do Estado da Bahia, Salvador, 1942.

LOPES, Thiago da Costa; MAIO, Marcos Chor. Comunidade e democracia na sociologia de T, Lynn Smith e José Arthur Rios. Revista Brasileira de Ciências Sociais, São Paulo, v.32, n.95, 2017.

MAIO, Marcos Chor. A história do Projeto Unesco: estudos raciais e Ciências Sociais no Brasil. Tese (Doutorado em Ciências Políticas) - IUPERJ, Rio de Janeiro, 1997.

. Arthur Ramos e a militância na Unesco. Anais da Biblioteca Nacional, Rio de Janeiro, n. 119, pp. 29-34, 1999.

MARCUSSI, Alexandre A. Implicações atuais do debate entre Herskovits e Frazier sobre os africanismos. In XXVI Simpósio Nacional de História, 2011, São Paulo. Anais do XXVI Simpósio Nacional de História. São Paulo: ANPUH-SP, 2011.

Diagonais do afeto: teorias do intercâmbio cultural nos estudos da diáspora africana. São Paulo: Intermeios/Fapesp, 2016.

\section{GANPHLAC}

Revista Eletrônica da ANPHLAC, ISSN 1679-1061, № 27, p. 185-221, Ago./, Dez., 2019.

http://revista.anphlac.org.br 
MARQUESE, Rafael de Bivar. História, antropologia e a cultura afro-americana: o legado da escravidão. Estudos Avançados, São Paulo, v. 18, n. 50, p. 303-304, 2004.

MARTÍNEZ-ECHAZÁBAL, Lourdes. O culturalismo dos anos 30 no Brasil e na América Latina: deslocamento retórico ou mudança conceitual? In: MAIO, Marcos Chor; SANTOS, Ricardo Ventura. Raça, Ciência e Sociedade. Rio de Janeiro: Fiocruz/CCBB, 1996, pp.107-124.

MICELI, Sérgio (Org.). História das Ciências Sociais no Brasil. v. 1. São Paulo: Sumaré/IDESP/FAPESP, 2001.

PALLARES-BURKE, Maria Lucia. Brasil, laboratório de civilização: a importância de Rüdiger Bilden. Revista de Ciências Sociais, João Pessoa, n. 39, pp. 179-194, Outubro de 2013.

PATTERSON, Orlando. Rethinking black history. Harvard Educational Review, v.41, n.3, pp. 297-315, 1971.

PEREIRA, João Baptista Borges. Emilio Willems e Egon Schaden na história da Antropologia. Estudos Avançados, São Paulo, v. 8, n. 22, pp. 249-253, set./dez. 1994.

RAMOS, Arthur. Guerra e relações de raça. Rio de Janeiro: Gráfica Perfecta, 1943.

O negro brasileiro: etnografia religiosa. Rio de Janeiro: Graphia, 2001.

Os grandes problemas da Antropologia brasileira. Mana, Rio de Janeiro, v.21, n.1, pp.195-212, abr. 2015. Disponível $<$ http://www.scielo.br/scielo.php?script=sci_arttext\&pid=S010493132015000100195\&lng=pt\&nrm=iso>. Acesso em 27 maio 2018.

SANSONE, Lívio. Estados Unidos e Brasil no Gantois: o poder e a origem transnacional dos estudos Afro-brasileiros, Revista Brasileira de Ciências Sociais, v.27, n.79, pp. 929, Junho,2012.

SCHWARCZ, Lilia Moritz. O Espetáculo das Raças: cientistas, instituições e questão racial no Brasil 1870-1930. São Paulo: Cia. das Letras, 1993.

SEGURA-RAMIREZ, Héctor Fernando. Tiro no pé: biopolítica, relações racializadas, academia e poder no Brasil (1823-1955/1997-2006). Tese (Doutorado em Ciências Sociais) - IFCH, Unicamp. Campinas, 2006.

\section{GANPHLAC}

Revista Eletrônica da ANPHLAC, ISSN 1679-1061, № 27, p. 185-221, Ago./, Dez., 2019.

http://revista.anphlac.org.br 
SILVA, Júlio Cláudio. História do nascimento dos estudos das culturas de origem africanas nas Américas (1930-1940). In XIV Encontro Nacional de História (Memória e Patrimônio), 2010, Rio de Janeiro. Anais... Rio de Janeiro: Anpuh/RJ, 2010.

SILVA, Sarah Calvi Amaral. Africanos e afro-descendentes nas origens do Brasil: raça, relações raciais e culturas negras no II Congresso Afro-Brasileiro de Salvador (1937). Revista Mundos do Trabalho, Florianópolis, v.7, n.13, jan./jun. 2015, p.193-214.

STOCKING Jr. George W. Introdução: Os pressupostos básicos da antropologia de Boas. In: STOCKING Jr. (org.). Franz Boas: a formação da antropologia americana (1883-1911), Rio de Janeiro: Contraponto: Editora UFRJ, 2004, p.15-38.

TAMANO, Luana Tieko Omena. A mestiçagem no microscópio: entre a detração e a particularização, permaneceu a democracia racial: uma análise de "A mestiçagem no Brasil" de Arthur Ramos (1930-1950). Dissertação (Mestrado em História Social) - USP. São Paulo, 2011.

VALENTINI, Luísa. Nos "arredores" e na "capital": as pesquisas da Sociedade de Etnografia e Folclore (1937-1939). Ponto Urbe: Revista do Núcleo de Antropologia Urbana da USP, São Paulo, n. 5, 2009. Disponível em: <https://journals.openedition.org/pontourbe/1355>. Acesso em: 27 maio 2018.

\section{GANPHLAC}

Revista Eletrônica da ANPHLAC, ISSN 1679-1061, № 27, p. 185-221, Ago./, Dez., 2019.

http://revista.anphlac.org.br 